\title{
Examining the Relationship between Foreign Purchase Liberalisation and Housing Affordability
}

\author{
Ema Izati Zull Kepili
}

School of Management, Universiti Sains Malaysia, 11800 USM, Pulau Pinang, Malaysia

*Email: emazull@usm.my

\begin{abstract}
This study attempts to examine the relationship between liberalisation of foreign purchase of properties and housing affordability in the presence of foreign direct investment (FDI) inflows. The negative relationship between liberalisation and affordability has caused dissatisfaction among Malaysians as house price has increased drastically since the government liberalise the foreign purchase of property. While Malaysia continues to receive FDI inflows which have been the engine for the country's economic growth, it would be appropriate to examine the relationships between the liberalisation of purchase for properties by foreigners and the housing affordability within this context. Utilising the Johansen Cointegration method, this research analysed the long-term relationship of liberalisation of foreign purchase within the property sector and affordability of terrace houses. Through the use of the Channel method, this research also examines the role of FDI in the relationship.
\end{abstract}

Keywords: Affordability, Channel Method, FDI, House prices, Johansen Cointegration

\subsection{INTRODUCTION}

Malaysia has deregulated its property sector in 2009, following the property liberaliation announcement made by the government in the same year. Among the liberalisation measures was the abolishment of the Foreign Investment Committee (FIC) approval given to foreigners who intend to purchase property in the country. The open policy has caused the Malaysian property sector to attract a high demand from all property sub-sectors which include residential and commercial properties. Although the liberalisation was intended to stimulate the property sector as well as the economy, it has been perceived that the spill over effect of this measure would be the increase of overall house prices.

On the external sector, Malaysia continues to receive foreign direct investment (FDI) inflows. Malaysia's moderate to strong growth was due to the flooding of FDIs since the mid-1980s. It is believed that not only FDI that has generated growth but the growth itself has motivated foreign firms to invest more into the country (Chowdhury and Mavrotas, 2005). It is also noted that FDI and gross domestic product (GDP) determine each other's stability. FDI has been a key driver underlying the strong growth performance experienced by the Malaysian economy. To attract a larger inflow of FDI, the government had introduced liberal incentives including allowing a larger percentage of foreign equity ownership in enterprise under the Promotion of Investment Act (PIA), 1986 (Karimi and Zulkornain, 2009). Today, with its market-oriented economy, combined with an educated multilingual workforce and a well-developed infrastructure, Malaysia is one of the largest regional and global recipients of FDI.

Nonetheless, the relationship between FDI or capital flows and the property sector were not 
discussed. Traditionally, the property sector was largely controlled by the government and the purpose of residential was shelter rather than investment. The effect of cross-border investment especially in greenfield investment might have stimulated the intention to own cross border properties. In the Post2000 s era, it is seen that many countries have initiated to liberalise their property sector. The IMF Global Housing Watch Report (2018) has shown that the real estate sector was booming especially in the developing economies. Real estate in these economies is sought after due to its dynamic growth, thus the demand for housing originated from both local and international expatriates (Cerutti, Dagher and Dell'Ariccia, 2017; Fagereng and Halvorsen, 2016). The local demand normally focuses in the urban area as it offer access to housing to those that had larger income disposal as compared to those in the rural areas. Opportunity for employment, urban amenities and utility consumption have been attributed to increasing household desires to live in an urban centre (Akinyode, 2017). On the contrary, foreign demand was largely attributed by the macro perspective of the country including political stability, economic prosperity, how friendly the new countries are and family factors (CesaBianchi, Cespedes and Rebucci, 2015). From the economic prosperity perspective, developing economies has been the targeted destination due to its openness to potential international buyers being it through trade or tourism. The dynamics of import and export transactions with other countries is normally extended with a foreign investment into the host country (Igan and Loungani, 2012). The foreign investment not only contributes to technological and managerial spill over but could attract foreign nationals to live in the host country as well.

Foreigners who want to live in other countries may have a different motivation than the locals. In the case of Malaysia, the increase in foreign nationals into the country might also be due to the liberalisation of the real estate sector (Wijburg and Aalbers, 2017). Malaysia, with the aboveperformance economic record, real estate liberalisation introduced by the government in 2009, was welcomed by potential international investors who were previously dissuaded by restrictions and bureaucracies. The direct impact of the liberalisation, which consequently attracted foreign purchasers, could be seen in the change in the entire Malaysian property landscape. Although the demand is seen to successfully solve the housing overhang issues, it has been deemed to cause the country's house price to increase significantly. This phenomenon is perceived to lead to housing affordability issues among the local population.

It is reported that Malaysia housing issues are not due to availability but rather concerns affordability. The Edge (2018) reported that availability, which is less of a concern as household size has been reduced from 5 to 4 , should be a long-term apprehension. The number of unsold residential units spiked in 2016-2017 (NAPIC, 2018) and this includes houses below RM250,000 which are sought after by the low and middle-income earners. There is also an increase in unsold units for houses priced between RM250,000-RM500,000 and this category of houses are normally the terrace house type. The affordability issue is glaring since young adults want to buy available houses but could not afford it. Two quick conventional solutions for the affordability issue have been put forward by the country, for example, loosening the credit facilities and building more houses that suit their budget. However, these solutions may not be sustainable. While the important factor for purchasing a house still lies on household or individual income, the possibility of increasing affordability at macro level ought to be considered. Since the government largely holds the policies on property sectors, it might be possible to examine the role of FDI as it has been successful in stimulating economic growth at the macro-level.

This study aims to examine the impact of liberalisation of foreign purchase of property on housing affordability, in the presence of FDI. An indirect method (Channel method) was employed to observe whether the inclusion of FDI along with liberalisation measure would alter the impact and relationship between liberalisation and housing affordability. The study will also attempt to estimate the liberalisation impact on the affordability level of the average house price in Malaysia, focusing on terrace house price. By comparing the magnitude of the impact, it would be useful to observe the impact of the liberalisation measures (and FDI) that would have affected the potential local terrace 
house purchasers that constitute the low and middle-income earners.

\subsection{LITERATURE REVIEW}

\subsection{Housing Affordability}

Housing affordability can be viewed from a subjective and relative perspective. Stone (2006) mentioned that the subjective concept assumes affordability is when people choose to live in a house they consider as affordable living style but did not elaborate on the characteristics of the living style mentioned. The relative concept, on the other hand, suggests the affordability level be observed based on time-series which allow for an area to be examined across time. The drawback of the relative concept is that it does not allow us to know whether the houses in the area are affordable or not (Jewkes and Delgadillo, 2010).

As data on housing began to increase in size, methods in defining housing affordability became more empirical. According to Meen (2018), four globally recognised housing affordability measures are i) house price to income ratio, ii) proportion of income spent on housing, iii) residual income measurement and iv) incorporating supply. The most popular method to define housing affordability is the house price to income ratio approach as it is straightforward and has been used in many countries. It is easy to construct where it calculates the percentage of income to housing-related expenses, normally mortgage payment. The approach gives the flexibility for the ratio to either use the gross or net income as the numerator. The approach, however, reveals little information which makes it unpopular among academic research.

The second approach is the proportion of income spent on housing. As a rule of thumb, households that spend more than $30 \%$ of their income on housing expenditure is said to be facing housing stress. A person is said to have a housing affordability problem when his housing cost (rental or mortgage payment) takes a large fraction of his household income. By rule of thumb, a simple $30 / 40$ rule (when the household income is at the bottom $40 \%$ of the income distribution level but is spending $30 \%$ on housing cost) provides an indicator that households are likely to be at risk of problems associated with a lack of affordable housing (Yates, 2007).

The third approach is residual income which focuses on the difference between income and housing costs instead of ratio. This approach looks at the household expenditure after housing costs have been deducted. Stone (2010) suggested two items to be considered under the operational residual income approach: the selection of a normative standard for non-housing items and the treatment of taxes. Meen (2018) does not think the measurement provides guidelines on the acceptable amount of residual income especially when the definition of poverty indicator is concerned.

The fourth approach, incorporating supply, gives more attention to the supply of homes available to the lowest income groups. According to Meen (2018), the measurement construct should incorporate supply elements such as vacancy rates to relate the number of housing units potentially affordable by different income groups to the total number of households in each income group. Notwithstanding the existing measurement, Meen (2018) proposed two affordability measures for consideration; that is low-income renter affordability and first-home buyer affordability.

The effects of increasing unaffordability issue are threefold. First, the potential house-buyers would be discouraged to purchase and own a home, therefore would see the diminishing records on homeownership. Second, the unaffordability issue would normally be associated with the higher income potential buyers, thus, requires a higher deposit. This would discourage buyers who are from the lower-income group. Third, due to higher house price, purchasers would be inclined to undertake larger loans with higher repayment to income ratios (facilitated in the past decade by the liberalisation of lending requirements). 


\subsection{Housing Market and International Capital Flows}

Research on housing affordability has expanded to acknowledge property liberalisation measures globally. The booming period of real estate sectors since early 2000 is the motivation for liberalisation. Accompanied by the ever-expanding cross-border capital flows, house price in host countries showed an increasing trend due to direct purchases from the expatriates or through indirect impact such as rapid urbanisation and open policies for foreigners to purchase although they are not working with any multinational corporations (MNCs). However, Favilukis, Kohn, Ludvigson and Van Nieuwerburg (2012) argued that changes in international capital flows played a small role in driving house price movements. The capital flows act as the key causal factor to financial market liberalisation. Using observations on credit standards, capital flows, and interest rates, it is found that credit supply explains $53 \%$ of the quarterly variation in house price growth in the U.S. over the period 1992-2010. However, when the credit supply is controlled, various measures of capital flow, real interest rates, and aggregate activity had collectively added less than 5\% to movements in home values. Thus, justifying that credit supply holds strong explanatory power for house price movements over the period 2002-2010 in a panel of international data, while capital flows have no explanatory power.

Despite Favilukis et al. (2012)'s findings, Richter and Werner (2016) believed that the relationship between the housing market and international capital flow exists. They maintained that the role of international capital flow on housing market moves in four transmission channels. By understanding these channels, Richter and Werner (2016) had iterated that the influence of capital flow on real estate can be evaluated more precisely. These identified channels are i) the transaction channel, ii) the direct credit channel, iii) an indirect credit channel about cross-border transactions of securitised housing loans and iv) the interest rate channel.

The transaction channel consists of direct transactions of residential property by nonresidents. Direct transactions also include foreign flows into real investment trusts (REITs) and property shares bought by foreign investors. Though purchasing host country's property could be regarded as a sensitive topic, high demand from foreigners reflects appreciation and confidence towards the country's property sector. Nonetheless, research on Spanish FDI pro-cyclical effects on housing price through transaction channel is mixed. The real estate sector showed insignificantly effect although foreign investment increased.

The second channel is the direct credit channel. It consists of mortgage lending from foreign bank' affiliates and purchases using mortgages in a foreign currency. In the case of Estonia, to attract foreign participation in their real estate market, the government expanded its credit accessibility, thereby increasing foreign loans. However, the policy caused concerning debt sustainability problem as local banks underestimated the risks involving foreign borrowings. While foreign credit poses a certain level of risk to the host country's financial institutions, foreign currency mortgages expose the country even more due to exchange rate risk, which could trigger debt vulnerabilities. The third channel is the indirect credit channel which emerged due to the increasing securitisation of mortgages. The difference between direct and indirect is that the latter deals with mortgage instruments which bundle single loans into commodious financial products. These mortgage instruments attract international investors as issues such as transfer risks, liquidity or arbitrage could be easier handled than single loans. How does the indirect credit channel impact capital flow on the housing market? It depends on the characteristics of the instrument, especially on the securitisation design.

The final channel is the interest rate. According to Richter and Werner (2016), flows into the other channels are themselves components of total capital flow, thus, may influence domestic interest rates. The interest rate transmission channel could be activated when excessive foreign capital flows into the domestic financial system which results in lower domestic mortgage rates. 
With the review of the literature on the foreign purchase of property and affordability, the study then looks into the examination of these two aspects with the presence of FDI.

\subsection{METHODOLOGY}

\subsection{Model Specifications}

This study aims to examine the housing affordability in the presence of external influence i.e. FDI. The dependent variable is house affordability ratio which follows the income to mortgage payment calculation. Mortgage payment is calculated based on $4 \%$ (the average lending interest rate between 2000 and 2017) and 30 years mortgage tenure. The 30 years tenure is the normal length of payment in Malaysia. A higher ratio reflects high affordability level of the potential house purchasers.

This time-series study has 72 observations with the length specified for the study between Q1: 2000 and Q4: 2017. The quarterly data for all variables were obtained from the Valuation and Property Services Department (VPSD) and Bank Negara Malaysia. The basic model for this study is,

$$
l H A_{t}=\beta_{0}+\beta_{1} l L i b_{t}+\beta_{2} l F D I_{t}+\beta_{n} X_{n}+\varepsilon_{t}
$$

Where HA is housing affordability level, Lib is liberalization (proxied by 1 /interest rate), FDI is net foreign direct investment and $\mathrm{X}$ is control variables. All variables are in the log form. In Eq.1, we hypothesised that liberalisation will give a negative impact on affordability while FDI a positive impact on affordability. However, to capture the effect of FDI as an interaction variable, this research employs the Channel Method which allows us to calculate the indirect impact of property liberalisation on housing affordability through the FDI channel, following Wacziarg (1999)'s Channel Method and Masron and Yusop (2006) work on measurement of the indirect impact of trade on private domestic investment, government spending, manufacturing value-added and FDI.

In accommodating the Channel method, two sets of equation models were estimated;

$$
\begin{array}{cc}
l \mathrm{HA}_{j t=} \gamma_{0}+\gamma_{1} l F D I_{t}+\gamma_{2} l H P R_{j t}+\gamma_{3} G D P_{t}+\varepsilon_{t} & \text { Eq. } 2 \\
\mathrm{l} F D I_{t=} \delta_{0}+\delta_{1} l L i b_{t}+\delta_{2} l R G D P_{t}+\varepsilon_{t} & \text { Eq. } 3
\end{array}
$$

FDI is net foreign direct investment, Lib is liberalization proxied by 1 /interest rate, RGDP is real GDP, HA is housing affordability and HPR is house price while $\mathrm{j}$ represents the type of house (either average house price or terrace house price). All variables are in the log form. In Eq.2, we maintain the positive relationship hypothesis between FDI and HA. However, we expect house price would have a negative relationship with the housing affordability level. In Eq.3, we postulate that higher liberalisation would increase FDI. Table 1 summarises the calculation of the indirect impact.

Table 1: The Calculation of Indirect Impact via FDI Channel

\begin{tabular}{cccc}
\hline $\begin{array}{c}\text { Affordability } \\
\text { Channel (AC) }\end{array}$ & $\begin{array}{c}\text { Impact of FDI on } \\
\text { Affordability }\end{array}$ & $\begin{array}{c}\text { Impact of } \\
\text { liberalization on FDI }\end{array}$ & Indirect impact \\
\hline FDI & $\gamma_{1}$ & $\delta_{1}$ & $\gamma_{1} * \delta_{1}$ \\
\hline
\end{tabular}


The result in the indirect impact $\left(\gamma_{1} * \delta_{1}\right)$ is expected to be negative; however, the magnitude is of importance in order to observe the role of FDI in influencing liberalisation effect on housing affordability. Later, the comparison of the coefficients of $\beta_{1}$ and $\left(\gamma_{1} * \delta_{1}\right)$. will be made.

\subsection{Estimation Procedure and the Review}

The objective of this section is to explain the relevant econometric procedures in testing timeseries data. The unit root test using the Augmented Dickey-Fuller or ADF test (Dickey and Fuller, 1981) is used initially. These tests use the existence of a unit root as the null hypothesis. For every model (except Eq. 5), the test the possibility of the variables to cointegrate in the long-run is made. Due to limitations, this study has more than two variables in the model, testing for the existence of relationships in levels between variables in this study. The system-based reduced rank regression approach or also known as the Johansen vector autoregression approach (Johansen, 1988) is employed. The cointegrating relationship is observed using the Johansen's Maximum Likelihood procedure among the $I$ (1) variables. The procedure developed by Johansen which involves the identification of rank of them by the matrix $\Pi$ in the specification given below:

$$
\Delta Y_{t}=\delta+\Pi Y_{t-k}+\sum_{i=1}^{k-1} \Gamma_{j} \Delta Y_{t-k}+v_{t}
$$

Where $Y_{t}$ is a column vector of the $\mathrm{m}$ variables, $\Pi$ and $\Gamma$ are coefficients matrices, $\Delta$ is difference operator, $\mathrm{k}$ denotes the lag length and $\delta$ is constant. There are two tests provided, namely trace and maximal eigenvalue tests. The main importance of these two tests is both tests have no standard distributions under the null hypothesis, although approximate critical values are tabulated by Oswald-Lenum (1992). Nevertheless, Johansen and Juselius (1990) suggest that the maximal eigenvalue test is more powerful than the trace test.

Trace test:

$$
\lambda_{\text {trace }}(r)=-T \sum_{i=r+1}^{n} \ln \left(1-\hat{\lambda}_{i}\right)
$$

Maximal eigenvalue test:

$$
\lambda_{\text {trace }}(r, r+1)=-T \sum_{i=r+1}^{n} \ln \left(1-\hat{\lambda}_{r+i}\right)
$$

Where $r$ is the number of cointegrating vector, $\hat{\lambda}_{\text {is }}$ the estimate values of the characteristics roots obtained from the estimated $\Pi$ matrix, $\mathrm{T}$ is the number of usable observations. However, there are at least two major problems in using this approach. First, the small sample properties of this approach remains unknown and secondly, it is only applicable in the situation in which all variables are integrated at the order of 1 or I(1).

If there are more than two variables in the model, there is a possibility of having more than one cointegrating vector. The model might form several equilibrium relationships governing the joint evolution of all variables. In general, for $\mathrm{n}$ number of variables, a study can have up to $\mathrm{n}-1$ cointegrating vectors. In order to observe whether these cointegrating relationships exist, multivariate equation error correction approach, known as the vector error correction model (VECM) is employed.

\subsection{RESULTS AND DISCUSSION}

The ADF test of stationarity suggests that the variables are all stationary at first difference, I(1) (Table 2). Correlation results in Table 3 show the preliminary idea of the bivariate relationship 
e-issn: $2229-8568$

between the variables. It can be seen that the relationship between liberalisation and affordability levels are negatively correlated $\left(\rho_{L I B \mid H A}=-0.205 ; \rho_{L I B \mid H A_{T}}=-0.298\right)$ signifying the higher the liberalisation, the lower the affordability level. The relationship between net FDI and housing affordability is also negative $\left.\rho_{N F D I \mid H A}=-0.109 ; \rho_{N F D I \mid H A_{T}}=-0.022\right)$, signifying higher FDI would reduce affordability levels. The preliminary relationship however, is very small between FDI and terrace affordability. The inverse relationships also were suggested between house price and affordability level $\left.\rho_{N F D I \mid H A}=-0.652 ; \rho_{N F D I \mid H A_{T}}=-0.433\right)$ reflecting the higher the house price, the lower the affordability level. The long-term relationship however, will be provided based on the Johansen Cointegration test and VECM.

Table 2: ADF unit root test results

\begin{tabular}{lccc}
\hline & Level & First difference & Result \\
\hline HA_Malaysia & -1.278 & -3.111 & $I(1)$ \\
HPrice_Malaysia & $(0.63)$ & $(0.03)$ & \\
\multirow{2}{*}{ FDI } & 0.902 & -8.493 & $I(1)$ \\
& $(0.99)$ & $(0.00)$ & $I(1)$ \\
\hline
\end{tabular}

Table 3: Correlation results

\begin{tabular}{|c|c|c|c|c|c|c|c|}
\hline & $\mathrm{HA}$ & $H \boldsymbol{H} \_T$ & $L I B$ & NFDI & RHPM & RTPR & $R G D P$ \\
\hline$H A$ & 1.000 & & & & & & \\
\hline$H A \_T$ & 0.796 & 1.000 & & & & & \\
\hline$L I B$ & -0.205 & -0.298 & 1.000 & & & & \\
\hline$N F D I$ & -0.109 & -0.022 & 0.434 & 1.000 & & & \\
\hline RHPM & -0.652 & -0.441 & 0.728 & 0.545 & 1.000 & & \\
\hline$R T P R$ & -0.493 & -0.433 & 0.832 & 0.576 & 0.959 & 1.000 & \\
\hline$R G D P$ & -0.264 & -0.153 & 0.843 & 0.628 & 0.898 & 0.952 & 1.000 \\
\hline
\end{tabular}

Table 4 provides the cointegration results for the three models (Eq. 1, Eq. 2, Eq. 3). In this test, the results show the trace and max-eigen values are higher than the critical values given. Model 1 , 2 and 3 reject the null hypothesis of no cointegration, and suggest that there is at least one cointegrating relationship in the respective models. In order to justify the short-run dynamics and the long-run relationship, the VECM was adopted on these models.

Table 4: Johansen Cointegration Test

\begin{tabular}{ccccc}
\hline Null Hypothesis & Trace & $\mathbf{5 \% / 1 \% ~ C V ~ O L}$ & Max-Eigen & $\mathbf{5 \% / 1 \%} \mathbf{C V ~ O L}^{\mathbf{a}}$ \\
\hline \multicolumn{4}{c}{ Panel A (Model 2a): Housing affordability (Malaysia) ratio, } & FDI, Malaysia house price \\
$r=0$ & $37.204^{*}$ & 29.791 & $23.631^{*}$ & 21.131 \\
$r \leq 1$ & 13.57305 & 15.492 & 13.27471 & 14.264 \\
$r \leq 2$ & 0.298333 & 3.842 & 0.298333 & 3.842 \\
\hline
\end{tabular}

Panel B (Model 2b): Terrace housing affordability ratio, FDI, terrace price
$r=0$
31.044*
29.791
22.900 *
$r \leq 1$
8.143
15.492
7.931
14.264 

$r \leq 2$
0.212
3.842
0.212
3.842

Panel C (Model 3) : FDI, Liberalization, GDP

$\begin{array}{lcccc}r=0 & 38.317^{*} & 29.791 & 23.804^{*} & 21.131 \\ r \leq 1 & 14.514 & 15.492 & 14.399^{*} & 14.264 \\ r \leq 2 & 0.1145 & 3.842 & 0.115 & 3.842\end{array}$

$*(* *)$ denotes rejection of the hypothesis at the $5 \%(1 \%)$ level

${ }^{a}$ Osterwald -Lenum critical value

\subsection{VECM: Model 1}

Model 1 comprises of housing affordability, liberalisation, FDI and house price. The error correction coefficients show a negative sign and the results are highly significant in both models; ($0.05 ;-0.03$ respectively). As postulated, the coefficients for liberalisation are negative and highly significant for Model 1a (-3.918) and 1b (-8.604). The results suggest that higher liberalisation has reduced the affordability level among the potential average Malaysian house and also terrace house buyers. However, the results for house price contradict with the hypothesis put forward, suggesting higher house price has caused the affordability level to increase.

\subsection{VECM: Model 2}

Model 2a comprises of Malaysia housing affordability level, FDI, average Malaysia house price and GDP, while Model 2 comprises of terrace affordability level, FDI, terrace house price and GDP. The error correction coefficients show a negative sign and the result are highly significant in both models; $(-0.132 ;-0.502$ respectively). It identifies that $1.3 \%$ of the disequilibrium is corrected between one quarter or $5.2 \%$ between one year in the Malaysia housing affordability model, while $5.02 \%$ disequilibrium is corrected quarterly in the terrace housing affordability model.

Although FDI coefficient results follow the hypothesis of positive and significant relationship, Model 2a shows that FDI impacted HA larger in overall Malaysian housing affordability compared to terrace affordability ( 0.500 vs 0.173 ). Contrary to the negative hypothesis which we postulated for house price-affordability relationship, it is interesting that terrace house price has positive and significant relationship with housing affordability ( 0.955 and 0.514 respectively). The result reflects that higher house price has induced higher affordability level (0.955).

\subsection{VECM: Model 3}

Model 3 comprises of FDI, liberalisation and GDP. The error correction term in this model shows a negative sign and is significant, justifying the relationship within the variable. As expected, liberalisation impacted FDI positively and is significant at $1 \%$. The market size, however, did not affect FDI as anticipated. The negative result signifies a lower market size increases the FDI into the country. The impact of liberalisation presence is tested by using a dummy variable (Model 1a). The results show that the liberalisation period has a positive effect on FDI (0.649). Thus, from these tests, we assume that liberalisation opens up a wider opportunity for FDI inflows to the country.

Table 5 : VECM and long-run relationships

\begin{tabular}{cccccc}
\hline & $D V=H A$ & $D V=H A \_T$ & $D V=H A$ & $D V=H A T$ & $D V=F D I$ \\
Model & $1 \mathrm{a}$ & $1 \mathrm{~b}$ & $2 \mathrm{a}$ & $2 \mathrm{~b}$ & 3 \\
\hline
\end{tabular}


e-issn: $2229-8568$

\begin{tabular}{lccccc}
\hline Lib & $-3.918^{* *}$ & $-8.604^{* *}$ & & & $2.840^{\mathrm{a} * *}$ \\
& $(-5.00)$ & $(-5.12)$ & & & {$[3.22]$} \\
FDI & 0.286 & -0.378 & $0.500^{* *}$ & $0.173^{* *}$ & \\
& $(1.28)$ & $(-0.97)$ & $(5.12)$ & $(6.30)$ & \\
House Price & $1.971^{* *}$ & $5.923^{* *}$ & $0.955^{* *}$ & $0.514^{* *}$ & \\
& $(4.12)$ & $(4.34)$ & $(3.69)$ & $(3.69)$ & \\
GDP & & & $-1.094^{* *}$ & $-0.534^{* *}$ & $-2.211^{*}$ \\
& & & $(-4.26)$ & $(-5.34)$ & {$[-5.78]$} \\
C & -35.891 & -76.296 & 6.139 & 4.288 & 39.166 \\
Error correction & $-0.050^{* *}$ & $-0.027^{* *}$ & $-0.133^{* *}$ & $-0.502^{* *}$ & $-1.444^{* *}$ \\
term & $(-2.40)$ & $(-3.44)$ & $(-2.34)$ & $(-6.36)$ & $(-3.31)$ \\
R2 & 0.274 & 0.373 & 0.414 & 0.653 & 0.713 \\
Adjusted R2 & 0.100 & 0.223 & 0.210 & 0.487 & 0.559 \\
\hline
\end{tabular}

Following the results obtained from Table 5, the indirect impact of liberalisation on housing affordability through FDI is calculated. As mentioned in Eq. 3, the indirect impact $\left(\gamma_{1} * \delta_{1}\right)$ is expected to be negative; however, the magnitude is of importance to see the role of FDI in influencing the liberalisation effect. In Table 6, the result in the indirect impact is negative (Malaysia: 1.420 \& Terrace: 0.491). It suggests that the indirect impact of liberalisation on housing affordability is positive through FDI, thus, the higher the liberalisation, the higher the housing affordability when FDI is considered. FDI did not only change the expected direction of liberalisation-housing affordability relationship, but it also magnifies the impact. Through FDI, a higher liberalisation has increased the affordability level among potential house buyers including potential terrace house buyers. Our results are consistent with Favilukis, Kohn, Ludvigson and Van Nieuwerburg (2012) which agree with the role of capital flows on the housing market. Nonetheless, while they stressed that the impact was small; our results found that FDI played a significant impact that it changed the liberalisationaffordability relationship from negative to positive.

Table 6. Indirect impact of liberalization on housing affordability through FDI

\begin{tabular}{cccc}
\hline & $\begin{array}{c}\text { FDI on Housing } \\
\text { Affordability } \\
\text { (From Model 2) }\end{array}$ & $\begin{array}{c}\text { Liberalization on FDI } \\
\text { (From Model 3) }\end{array}$ & Indirect Impact \\
\hline Malaysia & 0.500 & $2.840^{\mathrm{a}}$ & 1.420 \\
Terrace & 0.173 & & 0.491 \\
\hline
\end{tabular}

In comparison with Model 1 where liberalisation was found to be negatively related to housing affordability in both situation (average Malaysian house price and terrace house price), the indirect impact proves that FDI can change the relationship direction making housing affordability higher even when the liberalisation is widened for residential property sector. Another finding worth mentioning is that this result is obtained through the FDI channel, which is not in the list of Richter and Werner (2016)'s transmission channel. Based on this result, it could be suggested that another channel of capital flow transmission into the housing market is through the spill over effect of FDI inflows.

\subsection{CONCLUSION}


Malaysia is among the top FDI recipients in the world and the country's growth has been depending on export-led growth strategies to expand its economy. Malaysia's real estate sector experienced a market boom, drawing in international capital flows and foreigners to purchase the country's property. At the height of the property sector, the government announced liberalisation measures by removing some restrictions and requirements which hinders international property investors from investing previously. The liberalisation has caused house price to increase drastically in the last 20 years, subsequently, which deem to be the root cause of the housing affordability problem. In this study, the observation of the impact of liberalisation of foreign purchase towards house price (average Malaysia house price and terrace house) in the presence of FDI is made. The Channel Method is used to see the role of FDI in influencing liberalisation effect on house price.

It can be concluded that FDI play a role in the liberalisation of foreign purchase-housing affordability relationship. The liberalisation of foreign purchase-housing affordability relationship has changed its sign to positive, which signifies that in the presence of FDI, liberalisation cost might have been traded off by a positive spillover effect. Thus, the purchase of a terrace house then becomes more affordable. FDI impacts terrace house purchase less than the average house. This is perhaps due to spillover effect of FDI that is much concentrated in urban areas where the average house price captures a wider spectrum of house types.

This study has proven that cross-border capital flows play a significant role in the housing market. The role of FDI may not be in directly, rather, it could be in terms of spillover effects towards the micro level of society. This study is only limited to houses within the definition of terrace houses which include low-cost terrace, medium-cost terrace, double storey terrace and townhouses. Since they may represent different purchaser profiles, the result may be just limited so as to reflect the average type of terrace house rather than customised one. Thus, it is imperative for any country to carefully examine the role of FDI on different economy class needs so the inflows would be appreciated throughout the grass root level.

\subsection{REFERENCE}

1. Akinyode, Babatunde Femi (2017). Determining factors for housing ffordability in Ibadan, Nigeria. Ethiopian Journal of Environmental Studies and Management. 10(5), 642-653.

2. Cerutti, E., Dagher, J., \& Dell'Ariccia, G. (2017). Housing finance and real-estate booms: a cross- country perspective. Journal of Housing Economics, 38, 1-13.

3. Cesa Bianchi, A., Cespedes, L. F., \& Rebucci, A. (2015). Global liquidity, house prices, and the macroeconomy: Evidence from advanced and emerging economies. Journal of Money, Credit and Banking, 47(S1), 301-335.

4. Chowdhury, A., \& Mavrotas, G. (2005). FDI and growth: a causal relationship (No. 2005/25). WIDER Research Paper.

5. Dickey, D. A., \& Fuller, W. A. (1981). Likelihood ratio statistics for autoregressive time series with a unit root. Econometrica: Journal of the Econometric Society, 1057-1072.

6. Fagereng, A., \& Halvorsen, E. (2016). Debt and household consumption responses. 1, 3-45

7. Favilukis, J., Kohn, D., Ludvigson, S. C., \& Van Nieuwerburgh, S. (2012). International 
e-issn: $2229-8568$

capital flows and house prices: Theory and evidence. In Housing and the financial crisis (pp. 235-299). University of Chicago Press.

8. Global Housing Watch Report (2018), International Monetary Fund. Retrieved from http://www. imf. org/external/research/housing/report/pdf/Q2_2018. pdf.

9. Igan, D., \& Loungani, P. (2012). Global housing cycles. International Monetary Fund. Retrieved from https://www.researchgate.net/publication/256038735_Global_Housing_Cycles

10. IMF Global Housing Watch (2018). Retrieved from http://www.imf.org/external/research/housing/

11. Jewkes, M., \& Delgadillo, L. (2010). Weaknesses of housing affordability indices used by practitioners. Journal of Financial Counseling and Planning, 21(1).

12. Johansen, S. (1988). Statistical analysis of cointegration vectors. Journal of economic dynamics and control, 12(2-3), 231-254.

13. Johansen, S., \& Juselius, K. (1990). Maximum likelihood estimation and inference on cointegration - with applications to the demand for money. Oxford Bulletin of Economics and statistics, 52(2), 169-210.

14. Karimi, M. S., \& Yusop, Z. (2009). FDI and economic growth in Malaysia. MPRA Paper 14999, University Library of Munich, Germany.

15. Masron, T. A., \& Yusop, Z. (2006). Optimum currency area criteria and volatility in ASEAN. Asian Academy of Management Journal of Accounting and Finance, 2(2), 1-17.

16. Meen, G. (2018). How should housing affordability be measured. UK Collaborative Centre for Housing Evidence.

17. NAPIC, Valuation. Property Service Department (2018). Transaction Data.

18. Richter, M., \& Werner, J. G. (2016). Conceptualising the Role of International Capital Flows for Housing Markets. Intereconomics, 51(3), 146-154.

19. Stone, M. E. (2006). What is housing affordability? The case for the residual income approach. Housing policy debate, 17(1), 151-184.

20. Stone, M. (2010). Shelter poverty: New ideas on housing affordability. Temple University Press.

21. The Edge. (2018, September 26). Housing in Malaysia: An issue of affordability, not availability. The Edge.

22. Wacziarg, R. (1999). Measuring the dynamic gains from trade. The World Bank.

23. Wijburg, G., \& Aalbers, M. B. (2017). The internationalization of commercial real estate markets in France and Germany. Competition \& Change, 21(4), 301-320.

24. Yates, J. (2007). Housing Affordability and Financial Stress: National Research Venture 3: Housing Affordability for Lower Income Australians. Australian Housing and Urban Research Institute. 


\section{APPENDIX}

Appendix A. VECM of Malaysia affordability, FDI, Malaysia house price (Table 5, Model 2a)

\begin{tabular}{|c|c|c|c|c|c|c|}
\hline \multicolumn{7}{|c|}{ Dep. Variable $=$ Malaysia Affordability } \\
\hline & (a) & (b) & (c) & (d) & (e) & (f) \\
\hline Lag & 2 & 3 & 4 & 5 & 6 & 7 \\
\hline FDI $(+)$ & $\begin{array}{c}0.312484 \\
(0.13177) \\
{[2.37147]}\end{array}$ & $\begin{array}{c}0.482933 \\
(0.16889) \\
{[2.85937]}\end{array}$ & $\begin{array}{c}0.500284 \\
(0.09777) \\
{[5.11717]}\end{array}$ & $\begin{array}{c}0.465139 \\
(0.06146) \\
{[7.56856]}\end{array}$ & $\begin{array}{c}0.298396 \\
(0.17248) \\
{[1.73005]}\end{array}$ & $\begin{array}{c}0.355210 \\
(0.10076) \\
{[3.52541]}\end{array}$ \\
\hline $\begin{array}{l}\text { Malaysia } \\
\text { price (-) }\end{array}$ & $\begin{array}{c}0.423337 \\
(0.30382) \\
{[1.39340]}\end{array}$ & $\begin{array}{c}-0.739600 \\
(0.40518) \\
{[-1.82537]}\end{array}$ & $\begin{array}{c}0.955312 \\
(0.25878) \\
{[3.69157]}\end{array}$ & $\begin{array}{c}1.054468 \\
(0.15034) \\
{[7.01372]}\end{array}$ & $\begin{array}{c}0.187140 \\
(0.32014) \\
{[0.58457]}\end{array}$ & $\begin{array}{c}0.867260 \\
(0.18805) \\
{[4.61179]}\end{array}$ \\
\hline GDP & $\begin{array}{c}-0.286642 \\
(0.33391) \\
{[-0.85845]}\end{array}$ & $\begin{array}{c}0.491476 \\
(0.43424) \\
{[1.13181]}\end{array}$ & $\begin{array}{c}-1.094118 \\
(0.25642) \\
{[-4.26695]}\end{array}$ & $\begin{array}{c}-1.154970 \\
(0.15104) \\
{[-7.64667]}\end{array}$ & $\begin{array}{c}0.026326 \\
(0.34229) \\
{[0.07691]}\end{array}$ & $\begin{array}{c}-0.793943 \\
(0.20871) \\
{[-3.80407]}\end{array}$ \\
\hline $\mathrm{C}$ & -4.023546 & -13.82444 & 6.139514 & 7.291531 & -8.932221 & 2.702731 \\
\hline $\begin{array}{l}\text { Error } \\
\text { correction } \\
\text { term }\end{array}$ & $\begin{array}{c}-0.131160 \\
(0.04381) \\
{[-2.99393]}\end{array}$ & $\begin{array}{c}-0.059155 \\
(0.02867) \\
{[-2.06326]}\end{array}$ & $\begin{array}{c}-0.132710 \\
(0.05675) \\
{[-2.33853]}\end{array}$ & $\begin{array}{c}-0.252803 \\
(0.07362) \\
{[-3.43405]}\end{array}$ & $\begin{array}{c}-0.237799 \\
(0.06293) \\
{[-3.77892]}\end{array}$ & $\begin{array}{c}-0.495959 \\
(0.13956) \\
{[-3.55381]}\end{array}$ \\
\hline R-squared & 0.245 & 0.278 & 0.414 & 0.521 & 0.641 & 0.675 \\
\hline $\begin{array}{l}\text { Adj. R- } \\
\text { squared }\end{array}$ & 0.130 & 0.104 & 0.210 & 0.292 & 0.410 & 0.398 \\
\hline $\begin{array}{l}\text { Sum sq. } \\
\text { resids }\end{array}$ & 0.252 & 0.241 & 0.191 & 0.156 & 0.117 & 0.105 \\
\hline S.E. equation & 0.065 & 0.067 & 0.062 & 0.060 & 0.055 & 0.056 \\
\hline F-statistic & 2.125 & 1.599 & 2.035 & 2.275 & 2.780 & 2.438 \\
\hline $\begin{array}{l}\text { Log } \\
\text { likelihood }\end{array}$ & 95.704 & 95.351 & 101.226 & 105.933 & 113.279 & 114.297 \\
\hline Akaike AIC & -2.484 & -2.393 & -2.484 & -2.543 & -2.686 & -2.634 \\
\hline Schwarz SC & -2.160 & -1.936 & -1.892 & -1.814 & -1.816 & -1.622 \\
\hline $\begin{array}{l}\text { Mean } \\
\text { dependent }\end{array}$ & -0.003 & -0.003 & -0.002 & -0.003 & -0.003 & -0.003 \\
\hline $\begin{array}{l}\text { S.D. } \\
\text { dependent }\end{array}$ & 0.070 & 0.071 & 0.070 & 0.071 & 0.071 & 0.072 \\
\hline
\end{tabular}

Appendix B. VECM of Terrace affordability, FDI, house price (refer Table 5, Model 2b)

\begin{tabular}{|c|c|c|c|c|}
\hline \multicolumn{1}{|l|}{ Dep. Variable = Terrace Affordability } & \multicolumn{5}{l|}{$(\mathrm{e})$} & $(\mathrm{f})$ \\
\hline & $(\mathrm{c})$ & $(\mathrm{d})$ & 7 & 8 \\
\hline Lag & 5 & 6 & 0.053555 & 0.071922 \\
& 0.172551 & 0.017808 & $(0.02465)$ & $(0.01759)$ \\
& $(0.02738)$ & $(0.02782)$ & {$[2.17223]$} & {$[4.08814]$} \\
\hline Terrace price (-) & {$[6.30132]$} & {$[0.64014]$} & 0.691986 & 0.687320 \\
& 0.513571 & 0.766902 & $(0.12235)$ & $(0.08579)$ \\
& $(0.13913)$ & $(0.12261)$ & {$[5.65586]$} & {$[8.01167]$} \\
\hline GDP & {$[3.69141]$} & {$[6.25462]$} & -0.553646 & -0.580928 \\
& -0.534738 & -0.565166 & $(0.08179)$ & $(0.05690)$ \\
& $(0.10006)$ & $(0.08244)$ & {$[-6.76896]$} & {$[-10.2094]$} \\
\hline C & {$[-5.34431]$} & {$[-6.85545]$} & 5.285076 & 5.633055 \\
\hline
\end{tabular}




\begin{tabular}{|l|c|c|c|c|}
\hline \multicolumn{7}{|c|}{$\begin{array}{r}\text { Error correction } \\
\text { term }\end{array}$} & $\begin{array}{r}-0.502392 \\
(0.07888) \\
{[-6.36886]}\end{array}$ & $\begin{array}{r}-0.773577 \\
(0.21139) \\
{[-3.65942]}\end{array}$ & $\begin{array}{r}-1.052393 \\
(0.30555) \\
{[-3.44422]}\end{array}$ & $\begin{array}{r}-1.281674 \\
(0.36686) \\
{[-3.49364]}\end{array}$ \\
\hline R-squared & 0.653 & 0.717 & 0.759 & 0.816 \\
\hline Adj. R-squared & 0.487 & 0.535 & 0.554 & 0.606 \\
\hline Sum sq. resids & 0.043 & 0.035 & 0.030 & 0.022 \\
\hline S.E. equation & 0.031 & 0.030 & 0.029 & 0.028 \\
\hline F-statistic & 3.941 & 3.943 & 3.698 & 3.892 \\
\hline Log likelihood & 148.608 & 152.562 & 154.989 & 161.107 \\
\hline Akaike AIC & -3.837 & -3.894 & -3.906 & -4.035 \\
\hline Schwarz SC & -3.107 & -3.024 & -2.894 & -2.879 \\
\hline Mean dependent & -0.004 & -0.004 & -0.004 & -0.003 \\
\hline S.D. dependent & 0.044 & 0.044 & 0.044 & 0.044 \\
\hline
\end{tabular}

Appendix C. VECM of FDI, LIB, GDP (Refer Table 5, Model 3)

\begin{tabular}{|l|c|c|c|c|c|c|}
\hline \multicolumn{1}{|c|}{ Dep. Variable $=$ FDI } & $(\mathrm{a})$ & $(\mathrm{b})$ & $(\mathrm{c})$ & $(\mathrm{d})$ & $(\mathrm{e})$ & $(\mathrm{f})$ \\
\hline \multicolumn{1}{|c|}{ Lag } & 1 & 2 & 6 & 7 & 9 & 10 \\
\hline Lib & $\begin{array}{c}3.780^{* *} \\
{[5.62]}\end{array}$ & $\begin{array}{c}-10.808^{* *} \\
{[-4.07]}\end{array}$ & $\begin{array}{c}2.609^{* *} \\
{[3.13]}\end{array}$ & $\begin{array}{c}2.840^{* *} \\
{[3.22]}\end{array}$ & $\begin{array}{c}-5.455^{* *} \\
{[-3.71]}\end{array}$ & $\begin{array}{c}-6.426^{* *} \\
{[-4.21]}\end{array}$ \\
\hline GDP & $\begin{array}{c}-2.770890 \\
{[-8.27468)}\end{array}$ & $\begin{array}{c}3.621594^{* *} \\
(1.24454) \\
{[2.90998]}\end{array}$ & $\begin{array}{c}-2.121310 \\
(0.36744) \\
{[-5.77324]}\end{array}$ & $\begin{array}{c}-2.211170 \\
(0.38204) \\
{[-5.78779]}\end{array}$ & $\begin{array}{c}1.330387 \\
(0.62914) \\
{[2.11463]}\end{array}$ & $\begin{array}{c}1.735436 \\
(0.65938) \\
{[2.63193]}\end{array}$ \\
\hline C & 55.15867 & -133.1721 & 36.49727 & 39.16642 & -65.46533 & -77.46837 \\
\hline $\begin{array}{l}\text { Error } \\
\text { correction } \\
\text { term }\end{array}$ & $\begin{array}{c}-0.451094^{* *} \\
(0.16264) \\
{[-2.77350]}\end{array}$ & $\begin{array}{c}-0.113486^{*} \\
(0.06834)\end{array}$ & $\begin{array}{c}-1.332328 \\
(0.35202)\end{array}$ & $\begin{array}{c}-1.444399 \\
(0.43552)\end{array}$ & $\begin{array}{c}-0.939101 \\
(0.33532)\end{array}$ & $\begin{array}{c}-0.971940 \\
(0.41708)\end{array}$ \\
\hline R-squared & 0.516 & 0.588 & {$[-3.78480]$} & {$[-3.31647]$} & {$[-2.80065]$} & {$[-2.33032]$} \\
\hline $\begin{array}{l}\text { Adj. R- } \\
\text { squared }\end{array}$ & 0.486 & 0.516 & 0.714 & 0.713 & 0.790 & 0.803 \\
\hline $\begin{array}{l}\text { Sum sq. } \\
\text { resids }\end{array}$ & 21.661 & 18.432 & 12.665 & 12.571 & 9.153 & 8.532 \\
\hline S.E. equation & 0.577 & 0.569 & 0.531 & 0.554 & 0.527 & 0.542 \\
\hline F-statistic & 17.337 & 8.130 & 5.919 & 4.636 & 4.424 & 3.816 \\
\hline $\begin{array}{l}\text { Log } \\
\text { likelihood }\end{array}$ & -58.271 & -52.103 & -39.076 & -38.733 & -28.669 & -26.559 \\
\hline Akaike AIC & 1.808 & 1.856 & 1.818 & 1.929 & 1.860 & 1.920 \\
\hline Schwarz SC & 1.968 & 2.215 & 2.487 & 2.705 & 2.855 & 3.027 \\
\hline $\begin{array}{l}\text { Mean } \\
\text { dependent }\end{array}$ & -0.005 & -0.001 & 0.014 & 0.004 & 0.004 & -0.003 \\
\hline $\begin{array}{l}\text { S.D. } \\
\text { dependent }\end{array}$ & 0.806 & 0.817 & 0.832 & 0.834 & 0.845 & 0.850 \\
\hline
\end{tabular}

